degree of priority which should be given to them; to receive progress reports ; and to ensure that work on all the items in the approved programmes is properly and promptly carried out; and that useful technical information that is obtained is adequately disseminated".

On the wider issues of training for management, the Board has now appointed Mr. N. G. Fisher to be principal for its proposed Staff College, and search is being made for suitable premises. In the meantime, courses for colliery managements, as well as for some of the technical staffs at the area and divisional offices, are being run at temporary accommodation. The recruitment and training of staff are being further strengthened by the creation of a Staff Department at headquarters under Sir Andrew Bryan (staff member of the Board); and four staff directors have already been appointed to divisional boards.

\section{Natural Gas near Crowborough, Sussex}

As part of the Gas Council's five-year search for natural gas in Great Britain, a second deep well is to be sunk in the area near Crowborough, Sussex, about a mile south-east of the first well. The arrangements are in the hands of the D'Arcy Exploration Company (a member of the B.P. group), which is undertaking the work on behalf of the Gas Council. The first well in the area, which has been carried down to a depth of about 4,500 ft., has revealed small shows of gas at several levels, and the results obtained from it, and from subsequent seismic surveys in the area, indicate that a further deep test is justified.

\section{The Institute of Biology}

THE Institute of Biology, now in its sixth year of existence, has elected as president Sir James Gray, who was one of those concermed with the initial moves which led to the foundation of the Institute and a vice-president during 1950-54. New council members for 1955 have been elected as follows: Prof. G. E. Blackman, Mr. N. W. Pirie (vice-presidents) ; Dr. N. E. Hickin (honorary treasurer); Mr. H. J. Bunker, Dr. R. J. C. Harris, Mr. F. R. Horne, Dr. A. S. Parkes, Dr. C. L. Smith. Honorary membership has been conferred on Lord Boyd Orr and Sir John Russell in recognition of their services both to biology and to the application of biology to the betterment of mankind. The membership of the Institute is now : 1,150 full members, 60 probationer members and 290 student members. The steady growth of membership has enabled the Institute to establish regional branches and to undertake an increasing range of activities. Further information about the Institute can be obtained from the General Secretary, Institute of Biology, Tavistock House South, Tavistock Square, London, W.C.l.

\section{Bibliography of Natural History}

A RECENT issue of the Journal of the Society for the Bibliography of Natural History (3, No. 2, 63; 1955 ) includes a number of items of considerable interest to scholars, including an address on the "Bibliography and the History of Science" by V. A. Eyles, and an important classified list of books of reference and bibliographical books on zoology by F. C. Sawyer, comprising the works of some 212 authors. V. A. Eyles also contributes a note on the earliest printed version (1788) of the "Theory of the Earth" by James Hutton.

\section{Natal Museum (1904-54)}

THE March number of the South African Journal of Science includes an article on the golden jubilee in 1954 of the Natal Museum. The Museum was originally sponsored by the Natal Society, which was formed in Pietermaritzburg in 1851. The Society soon acquired museum objects, which were moved from site to site until the final move was made to the present premises in Theatre Lane. Eventually it became evident that the Museum had outgrown the resources of the parent body, and the Government assumed responsibility in 1904. A series of functions was arranged to commemorate this event, the most notable being a gathering on November 30,1954 , in the Museum. An illustrated brochure on the history and development of the Museum has been published.

\section{Oundle School Natural History Society}

A FINE example of voluntary effort is the report of the Oundle School Natural History Society for 1954. Apart from its varied contents, the printing, duplicating and reproduction of photographs in the report have been tackled with enthusiasm and have led to a publication which will undoubtedly give pleasure to all who study the natural history of Northamptonshire. Besides the usual notes recording observed fauna and flora, the report contains a short article on the emergence of the hornet clearwing moth, an account of butterfly-collecting in the south of France and northern Spain and of some Welsh beetles, and a description of the distribution of Spirorbis spirillum and $S$. borealis on the shore at Millport.

\section{Discovery}

THE latest issue of Discovery (26, No. 4; April 1955) contains the usual series of articles on varied aspects of science which are of topical interest and which have been written for the intelligent layman and for the man of science who wishes to keep himself informed of developments in other fields. Among them is an account by Dr. G. Curzon of mescalin and its physiological and psychological effects. The development of automatic factories is described by Dr. S. Lilley, who gives some details of the sequence of operations in the automatic production line at a Moscow piston factory. Prof. C. M. Yonge has written an illustrated article on giant clams, while R. G. Rose contributes a short description of the life of Carl Frederick Gauss. There is also an interesting article by James Paton explaining how the Observatory on Ben Nevis came into being and fell into decay.

\section{The Science Masters' Association}

There can be few voluntary organizations which, over a period of thirty-two years, are able to show a steady rise in membership each year. Despite the Second World War, the Science Masters' Association showed a steady increase in membership from 364 in 1919 to 4,540 in 1952. In 1953 there was a slight decline in membership; but it is pleasing to note in the annual report for 1954 that membership again showed an upward trend. The contribution made by this Association to the quality of science teaching in schools by means of regular meetings, an annual conference and the publication of its excellent journal, the School Science Review, is immeasurable. Among special items referred to in the report are the inquiry made by the Association into the deterioration of science teaching caused by the shortage of science masters; the findings of a sub-committee on 